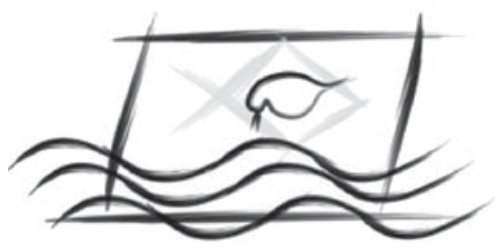

ECOTOX - Brazil
J. Braz. Soc. Ecotoxicol., v. 4 n. 1-3, 2009, 83-86

doi: $10.5132 /$ jbse.2009.01.011

Short Comunication

\title{
Investigation of Copper Binding to Hydrosoluble Proteins of an Amphipod
}

\author{
G. L. L. Pinho ${ }^{1 *}$, R. Saint-Louis ${ }^{2}$, A. Bianchini ${ }^{1} \&$ E. Pelletier ${ }^{2}$ \\ ${ }^{1}$ Universidade Federal do Rio Grande (FURG), Av. Itália km 8, Rio Grande, \\ Rio Grande do Sul, Brasil, CEP 96.201-900 \\ ${ }_{2}^{2}$ Institut des Sciences de la Mer de Rimouski (ISMER), Université du Québec à Rimouski, 310 , \\ Allée des Ursulines, C.P. 3300 Rimouski (Quebec) Canada G5L3A1
}

(Received December 5, 2008; Accepted August 19, 2009)

\begin{abstract}
This study investigated the body copper accumulation in the amphipod Gammarus sp.. Groups of copper-binding proteins were also investigated considering their molecular weights. Regarding copper accumulation, a saturation type kinetics was observed with $\mathrm{K}_{\mathrm{m}}$ and $\mathrm{V}_{\max }$ values of $0.48 \mathrm{mg} \mathrm{Cu} . \mathrm{L}^{-1}$ and $713.3 \mu \mathrm{g} \mathrm{Cu} . \mathrm{g}^{-1} \mathrm{dw}$, respectively. Size exclusion chromatography ( 5 to $150 \mathrm{KDa}$ ) associated with ICP-MS showed that most of copper-binding proteins in Gammarus sp. have molecular weights $<12 \mathrm{KDa}$, probably corresponding to metallothioneins.
\end{abstract}

Keywords: copper accumulation, Gammarus sp., ICPMS, metallothioneins, size exclusion chromatography.

\section{RESUMO}

\section{Investigação da ligação do cobre às proteínas hidrossolúveis de um anfípodo}

Este estudo investigou a acumulação corporal do cobre no anfípodo Gammarus sp.. Grupos de proteínas ligadas ao cobre foram também investigadas considerando seu peso molecular. Em relação à acumulação de cobre, foi observada uma sinética do tipo saturação com valores de $\mathrm{K}_{\mathrm{m}}$ e $\mathrm{V}_{\max }$ de $0,48 \mathrm{mg} \mathrm{Cu} \cdot \mathrm{L}^{-1}$ e $713,3 \mu \mathrm{g} \mathrm{Cu} . \mathrm{g}^{-1} \mathrm{ps}$, respectivamente. A cromatografia de exclusão por tamanho (5 a $150 \mathrm{KDa})$ associada ao ICP-MS, mostrou que a maioria das proteínas ligadas ao cobre em Gammarus sp. têm peso molecular $<12 \mathrm{KDa}$, provavelmente correspondendo às metalotioneínas.

Palavras-chave: acumulação de cobre, cromatografia de exclusão por tamanho, Gammarus sp., ICPMS; metalotioneínas.

\section{INTRODUCTION}

Aquatic invertebrates can accumulate metals in their body, at different concentrations, whether or not this metal is essential to the metabolism. In the case of crustaceans, tissue and body concentrations of trace metals vary greatly (Rainbow et al., 1989). Specifically to amphipods, both essential and non-essential metals are accumulated without excretion (Rainbow et al., 1989).

Trace metals potentially bind to any macromolecule exhibiting affinity for them. Since they have typically affinity for sulphur and nitrogen (Nieboer \& Richardson, 1980), and proteins are made up of amino acids containing these chemicals, there is no shortage of potential binding sites for trace metals in cells (Rainbow, 1997). Metal detoxification often involves binding proteins, such as metallothioneins (Viarengo, 1989). These proteins have a low molecular weight and they are capable to sequester metals, primarily copper, zinc, cadmium and mercury. Functions of metallothioneins are not completely understood, but it is accepted that their main function is 
associated with the homeostase of essential metals, such as copper and zinc (Brady, 1982).

\section{MATERIAL AND METHODS}

Gammarid amphipods (Gammarus sp., $125.5 \pm 20.1 \mathrm{mg}$ ) were collected in the Saint Lawrence Estuary (Rimouski, Quebec, Canada), and adult males were transported to the laboratory for acclimation in filtered sea water (natural water from Saint Laurance, $0.7-1.0 \mu \mathrm{m}$ ), at salinity 27 and $14{ }^{\circ} \mathrm{C}$ of temperature. Copper $\left(\mathrm{CuCl}_{2} .2 \mathrm{H}_{2} \mathrm{O}\right)$ exposure was performed via water for 5 days, in duplicate, using glass flasks containing $500 \mathrm{~mL}$ of experimental medium continuously aerated, with 10 amphipods in each flask, in a semi-static condition (medium exchanged each $24 \mathrm{~h}$ ). Nominal metal concentrations added to the water were $0.1,0.5,1.0,5.0$ and $10.0 \mathrm{mg} \mathrm{Cu} . \mathrm{L}^{-1}$.

After exposure, the surviving amphipods from each tested concentration were cleaned in salt water without copper, dried with paper, pooled, lyophilized, powdered, weighed and prepared for three different analyses:

a) Total copper accumulation, where an aliquot of wholebody Gammarus powder $(50 \mathrm{mg})$ after acid digestion ( $1 \mathrm{~mL}$ of $\mathrm{HNO}_{3}$ and $0.5 \mathrm{~mL}$ of $\mathrm{H}_{2} \mathrm{O}_{2}$ for $2 \mathrm{~h}$ in water bath at $80{ }^{\circ} \mathrm{C}$ ) by Inductive Coupled Plasma - Mass Spectrometry (ICP-MS);

b) Protein molecular weights (MWs), after aqueous extraction, where sub-samples $(0.1 \mathrm{~g})$ from Gammarus powder were extracted with $1.4 \mathrm{~mL}$ of water by shaking in a water bath at $37{ }^{\circ} \mathrm{C}$ for $24 \mathrm{~h}$. After extraction, samples were centrifuged at $10.000 \times \mathrm{g}$ for $20 \mathrm{~min}$. Supernatants were analyzed on an HPLC column (5-150 KDa, Alltech Prosphere $125 \mathrm{HR}$ ) by Size Exclusion Chromatography (SEC). Injected volume was $100 \mu \mathrm{L}$. MWs were determined by relating the time of protein peaks from samples with that from standard proteins used for calibration (Sigma, MWGF-200: Gel Filtration Molecular Weight Markers 12440 to $200000 \mathrm{Da}$ ); and

c) Distribution of copper-binding proteins, determined using the same SEC column coupled to ICP-MS, following the same chromatographic conditions of pressure and elution rate. Retention time of copper peaks (detected by ICP-MS) were related with those from proteins (detected by spectrophotometry), indicating the MWs of copper-binding proteins.

\section{RESULTS AND DISCUSSION}

The average mortalities after 5 days of experiment in each tested copper concentration were: $0,20,45,60,50$ and $70 \%$, in control (no copper exposure), 0.1, 0.5, 1.0, 5.0 and $10.0 \mathrm{mg} \mathrm{Cu} \mathrm{L}^{-1}$, respectively. Different percentage of mortality were tested with intention to evaluate until which concentration organisms have capacity to use defense strategies against copper exposure. It was not possible to kill more than $70 \%$ of organism in a soluble copper concentration. Regarding the whole body copper burden in surviving amphipods, a clear saturation type kinetics as a function of the metal concentration in the experimental medium was observed. $\mathrm{K}_{\mathrm{m}}$ and $\mathrm{V}_{\max }$ values were calculated as $0.48 \mathrm{mg} \mathrm{Cu} . \mathrm{L}^{-1}$ and $713.3 \mathrm{mg} \mathrm{Cu} . \mathrm{g}^{-1} \mathrm{dw}$, respectively. Interpretation of whole body copper accumulation kinetics indicates that there is a simple absorption of the dissolved metal into the biological tissues, where the metal binds with an affinity $\left(\mathrm{K}_{\mathrm{m}}\right)$ for sites available up to a certain limit of saturation $\left(\mathrm{V}_{\max }\right)$.

A typical protein chromatogram for control amphipods and retention time of standard proteins is shown in Figure 1a. Apart from the chromatogram corresponding to the highest concentration tested $\left(10 \mathrm{mg} \mathrm{Cu} . \mathrm{L}^{-1}\right)$, where a different peak in a retention time between 16 and $18 \mathrm{~min}$ was observed (Figure 1b), all chromatograms were very similar to the control one (Figure 1a).

After analysis with ICP-MS, chromatograms showed an increase in the peak representing the copper-binding proteins paralleled by a decrease in the zinc peak at retention time between 12 and $16 \mathrm{~min}$ after exposure to $10 \mathrm{mg} \mathrm{Cu} . \mathrm{L}^{-1}$ for 5 days (Figure 2).

This $\mathrm{Zn}-\mathrm{Cu}$ exchange was tested putting copper (equivalent to $10 \mathrm{mg} . \mathrm{L}^{-1}$ ) directly on a sample of powdered control organism and the metals exchange was not verified. It is an indication that this $\mathrm{Zn}-\mathrm{Cu}$ exchange was during copper exposure and an internal behavior. Chromatograms for the other copper
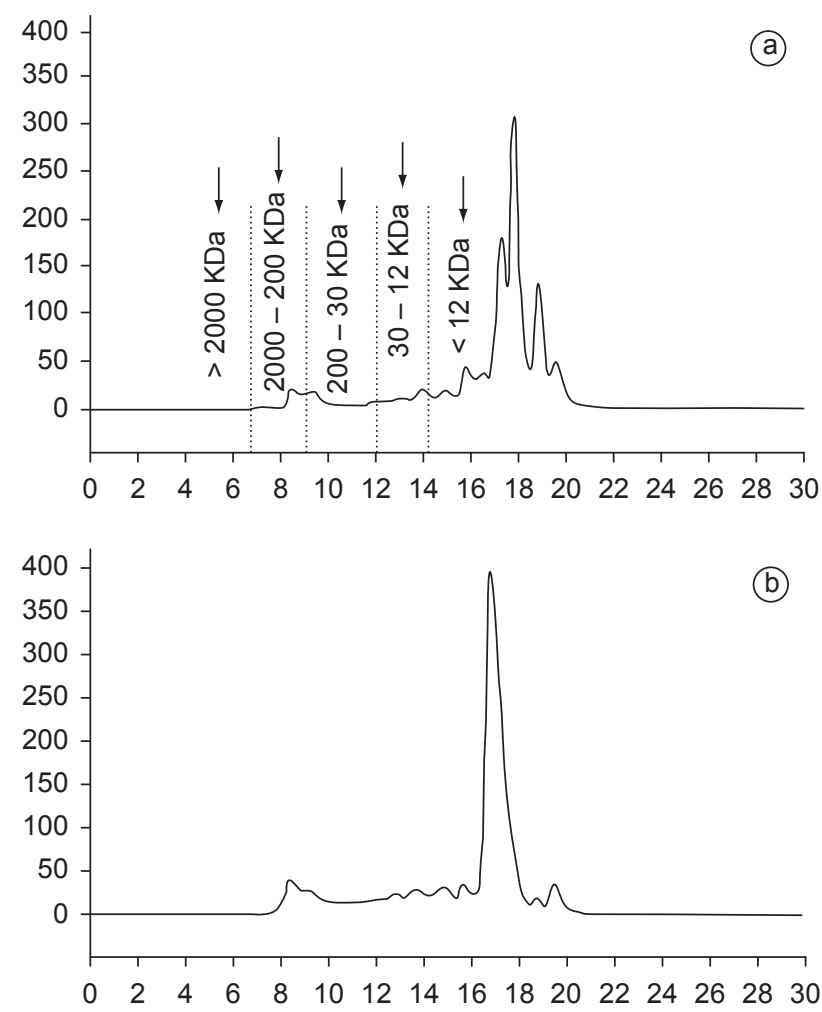

Figure 1 - Chromatogram of Gammarus sp. maintained under control conditions a) or exposed to $10 \mathrm{mg} \mathrm{Cu} . \mathrm{L}^{-1}$ for 5 days; b). Chromatogram was obtained by Alltech Prosphere $125 \mathrm{HR}$ analytical column with HPLC at $240 \mathrm{~nm}$. Groups of proteins are separated by the vertical dotted lines, according to their molecular weights, which were determined by the retention time of standard proteins. 

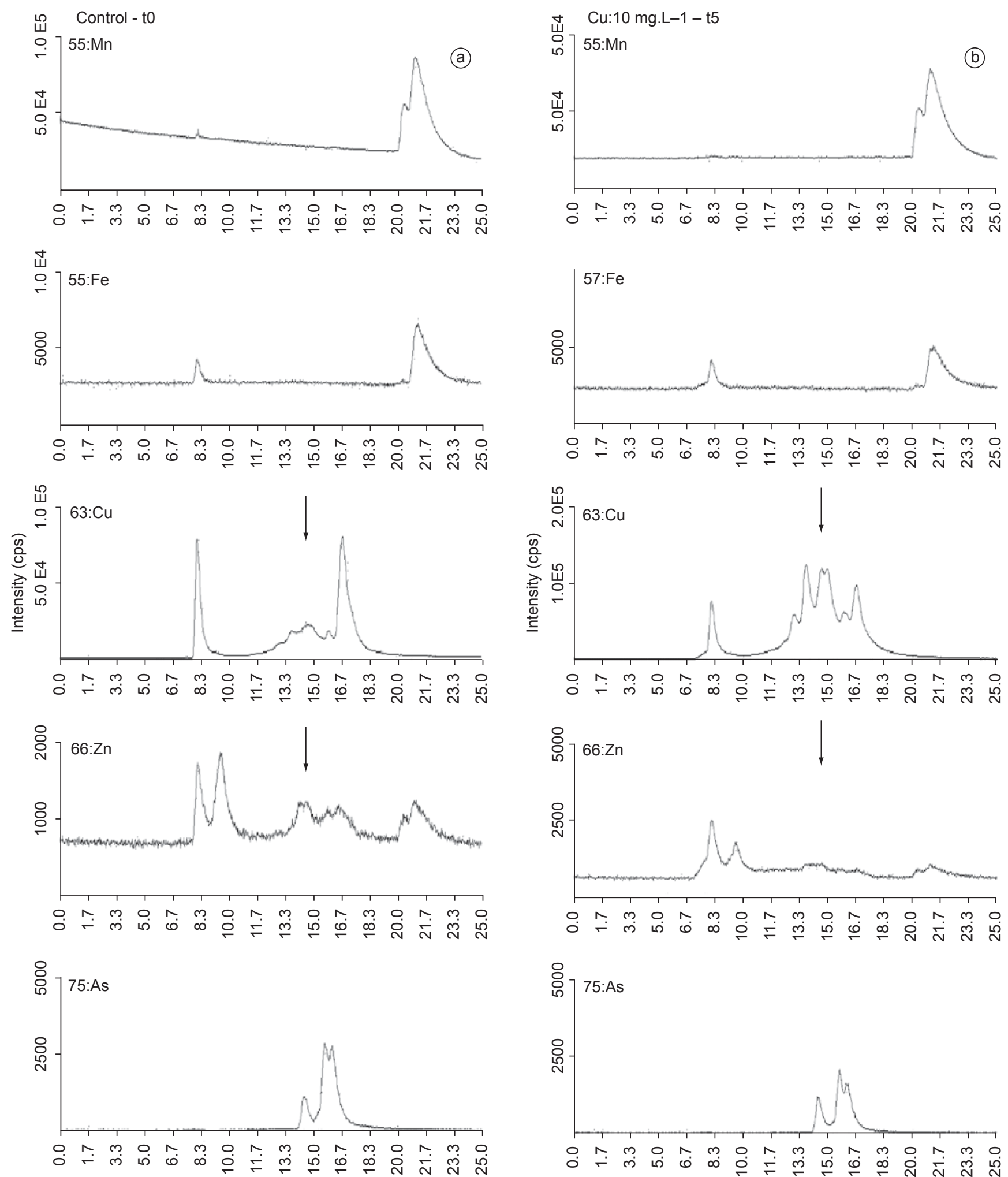

Retention time (min)

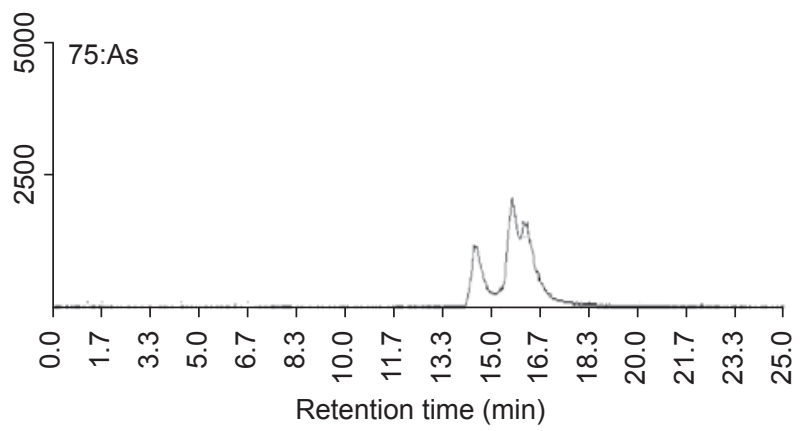

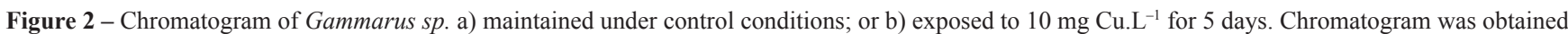
by Syze Exclusion Chromatography (SEC) column (Alltech Prosphere $125 \mathrm{HR}$ analytical column) coupled to Inductive Coupled Plasma Mass Spectrometry (ICP-MS). Peaks were detected by ICP-MS for five different metals ( $\mathrm{Mn}, \mathrm{Fe}, \mathrm{Cu}, \mathrm{Zn}$, and As).

concentrations tested are not shown. However, it was observed a gradual increase in the copper peak concomitant with a reduction in the zinc peak, as the copper concentration was raised in the experimental medium. This finding suggests that there is a replacement of zinc by copper in the same range of retention time, i.e., in the same range of protein MWs, as 
copper concentration was raised in the experimental medium. Binding affinity of different metals for metallothioneins varies considerably, but a pattern of increasing affinity is reported as $\mathrm{Zn}<\mathrm{Pb}<\mathrm{Cd}<\mathrm{Cu}<\mathrm{Ag}=\mathrm{Hg}=\mathrm{Bi}$, thereby making zinc readily displaceable by other metals, including copper (Kagi, Kojima, 1987).

Considering the sensitivity of the column used (5 to $150 \mathrm{KDa}$ ) and results from standard proteins (Figure 1), molecular weights of water soluble proteins analyzed in Gammarus sp. are mostly $<12 \mathrm{KDa}$. In addition, it was at MWs $<12 \mathrm{KDa}$ that a modification in protein chromatogram and a copper peak after ICP-MS analysis were observed. Taken these findings together, changes observed seem to be part of a biochemical response of amphipods to copper exposure, aiming a protective action against copper toxicity.

Comparing chromatograms of the extreme situations tested (control conditions and exposure to $10 \mathrm{mg} \mathrm{Cu} . \mathrm{L}^{-1}$ ), it was observed a higher quantity of proteins and peaks representing copper-binding proteins with $\mathrm{MWs}<12 \mathrm{KDa}$. This result is in close agreement with that reported for the Antarctic krill (Li et al., 2005). Using different SEC columns, these authors verified that the highest copper distribution (59\%) was associated with proteins of MWs between 2 and $20 \mathrm{KDa}$, followed $(36 \%)$ by those with MWs $<2$ KDa. Worth noting is that these results were obtained from animals collected directly from the field, without experimental copper exposure in laboratory. This finding clearly indicates that a baseline amount of copper-binding proteins is normally present under natural conditions. Under the experimental conditions employed in the present study, it is likely that the amount of these proteins was increased after experimental exposure to copper, resulting in a higher copper accumulation in tissues than that observed under natural conditions. Since both studies used similar techniques to analyze whole body copper accumulation, when krill data (Li et al., 2005) are compared with data from control amphipods (Gammarus sp.) tested in the present study, an $\sim 10$-fold higher copper accumulation is observed in the gammarids ( $\mathrm{krill}=7.4$ and Gammarus sp. $\left.=78.4 \mu \mathrm{g} \mathrm{Cu} . \mathrm{g}^{-1} \mathrm{dw}\right)$. Other values reported in the literature for two krill species from Central California (Euphausia pacifica and Thysanoessa spinifera) and the Antarctic krill (Euphausia superba) varied between 32 and $65 \mu \mathrm{g} \mathrm{Cu} . \mathrm{g}^{-1} \mathrm{dw}$ (Sydeman and Jarman, 1998; Nygard et al., 2001), being closer to that reported for gammarids in the present study.

Metal detoxification often involves binding proteins, such as metallothioneins (Viarengo, 1989). Authors indicate that metallothioneins play an important role in the homeostasis of essential metals such as $\mathrm{Cu}$ and $\mathrm{Zn}$; they can act as essential metal stores to fulfill enzymatic and other metabolic demands as well as in the sequestration of nonessential metals, such as Cd and Hg (Amiard, et al., 2006; Coyle et al., 2002). Copper is known to bind to metallothioneins or metallothioneins-like proteins, which in mammals and other vertebrates usually have a range of MWs from 6-15 KDa. Data reported in the present study showed that in Gammarus sp. copper was mostly bound to water soluble proteins with MWs between 30 and $12 \mathrm{KDa}$ and
$<12$ KDa. Proteins with MWs $<12$ KDa might be equivalent to the copper-binding metallothioneins in Gammarus sp., but, as observed at present results, other proteins are also involved in copper accumulation in this species. This statement is based on the fact that proteins with MWs $>15 \mathrm{KDa}$ (maximum MWs of metallothioneins reported in the literature) were shown to be bound to copper. The change in protein chromatograms observed at the highest copper concentration tested, associated with the copper peaks detected by ICP-MS at the same MWs range, might be an indication of a mobilization of some unknown proteins, other than metallothioneins, to counteract the exposure to high copper concentration.

Acknowledgments - This work was financially supported by the Canada Research Chair in Molecular Ecotoxicology applied to high latitude coastal ecosystems (E.P.) and Institute des Sciences de la Mer de Rimouski (ISMER/UQAR). Pinho G.L.L. was a graduated fellow from the Brazilian CNPq. Bianchini A. is a research fellow from the Brazilian $\mathrm{CNPq}$ (\# 302734/2003-1).

\section{REFERENCES}

AMIARD, J.-C., AMIARD-TRIQUET, C., BARKA, S., PELLERIN, J. \& RAINBOW, P.S., 2006, Rewiew. Metallothioneins in aquatic invertebrates: Their role in metal detoxification and their use as biomarkers. Aquat. Toxicol., 76: 160-202.

BRADY, F.O., 1982, Physiological function of metallothionein. Trends Biochem. Sci., 7: 143-145.

COYLE, P., PHILCOX, J.C., CAREY, L.C. \& ROFE, A.M., 2002, Review. Metallothionein: The multipurpose protein. Cell. Mol. Life Sci., 59: 627-647.

KAGI, J.H. \& KOJIMA, Y., 1987, Chemistry and biochemistry of metallothionein. Experientia Supll., 52: 25-61.

LI, B., BERGMANN, J., LASSEN, S., LEONHARD, P. \& PRANGE, A., 2005, Distribution of elements binding to molecules with different molecular weights in aqueous extract of Antarctic krill by size-exclusion chromatography coupled with inductively coupled plasma mass spectrometry. J. Chromatogr., 814: 83-91.

NIEBOER, R. \& RICHARDSON, D.H.S., 1980, The replacement of the nondescript term 'Heavy Metals' by a biologically and chemically significant of metal ions. Environ. Pollut., 1 : 3-26.

NYGARD, T., LIE, E., ROV, N. \& STEINNES, E., 2001, Metal dynamics in an Antarctic food chain. Mar. Pollut. Bull., 42: 598-602.

RAINBOW, P.S., 1997, Trace metal accumulation in marine invertebrates, marine biology or marine chemistry. J. Mar. Biol. Assoc. UK., 77: 195-210.

RAINBOW, P.S., MOORE, P.G. \& WATSON, D., 1989, Talitrid amphipods as biomonitors for copper and zinc. Est. Coast. Shelf. Sci., 28: 567-582.

SYDEMAN, W.J. \& JARMAN, W.M., 1998, Trace metals in seabirds, Steller sea lion, and forage fish and zooplankton from central California. Mar. Pollut. Bull., 36: 828-832.

VIARENGO, A., 1989, Heavy metals in marine invertebrates: mechanisms of regulation and toxicity at the cellular level. Rev. Aquat. Sci., 1: 295-317. 